\title{
The Factors Affecting Regional Expenditures on Regency/Municipality in South Sumatera Province
}

\author{
Nurhasanah Nurhasanah ${ }^{1}$ M. Thoyib ${ }^{1}$ Sherly Amerta Agustina, ${ }^{1, *}$ \\ ${ }^{1}$ Sriwijaya State Polytechnic \\ ${ }^{*}$ Corresponding author.Email: amertasherly@gmail.com
}

\begin{abstract}
This study aims to determine the Factors affecting Regional Expenditures on Regency/Municipality in South Sumatera Province. The population in this study is 17 Regency/Municipality in South Sumatera Province. This study is a quantitative study that will use secondary data from the official website of the Directorate General of Fiscal Balance (www.djpk.kemenkeu.go.id) with Time-Series data is used in 2016 to 2020 (5 years) and Cross-section data is 17 Regency/Municipality, so the panel data or samples used are 85 panels or samples. Data analysis techniques in this study are statistic descriptive, classical assumption test, multiple linear regression test, and hypothesis test with SPSS For Windows Version 25.00 program. The results of data analysis indicate that simultaneously Local Tax, Retributions, Balance Funds, Other Legitimate Regional Income and Excess of Budget Calculation have a positive effect to Regional Expenditures. Partially Local Tax, Balance Funds, Other Legitimate Regional Income and Excess of Budget Calculation have a positive effect to Regional Expenditures. Moreover, Retributions has no effect to Regional Expenditures. The Balance Funds is most dominant in influencing Regional Expenditures.
\end{abstract}

Keywords: Regional Expenditures, Local Tax, Retributions, Balance Funds, Other Legitimate Regional Income and Excess of Budget Calculation.

\section{INTRODUCTION}

When regional revenues increase it has positive effect on regional expenditures because, Regional Expenditures depend on dengan regional revenues. Every year regional expenditures must increase, so it can increase public welfare and triggering the opportunities for regional revenues both in terms of tax and retribution. In 2020, regional revenues and expenditures actually decreased due to the COVID-19 pandemic. Reported from (Tempo.co, 2020) "During covid-19. regional expenditures decrease and only $16 \%$ ". The decrease of regional expenditures in 2020 was influenced by the decreased of regional revenues which become to Rp2,630,380,697,412 due to the covid-19 pandemic. Regional revenue which tends to decrease consists of; Local Tax, Retributions, Balance

Funds, Other Legitimate Regional Income and Excess of Budget Calculation.

Local tax have decreased from 2019 to 2020. Reported from (BritaBrita.com, 2020) "The Head of the South Sumatra Bapenda explained that local tax revenues in 2020 decreased to 3-4 billion per day due to the covid-19 pandemic". The decrease of local tax revenues in 2020 requires government to find solutions, one of them is provide tax relief program for vehicle which is expected to increase local tax. The condition of local taxes can effect regional expenditures, regional expenditures will decrease ewhen local tax decrease. It is happened because regional expenditures determined by regional revenues, one of them is local tax.

Retributions is regional revenues that must be given attention by the government, because by increasing retribution it will give effect on increasing regional revenues so it can trigger regional expenditures to increase. South Sumatra's retribution are still below expectation and tend to decrease, it is because the system of retribution collection in South Sumatra is less precise and need to improved. One of the retribution systems that must be improved is parking retribution system in regencies/cities in South Sumatra, because reported by (Sripoku.com, 2020) "Parking retribution on Regency/city in South Sumatra bellow the target, because some parking points were controlled by illegal parking attendant who do not deposit the retribution collection to department of transportation so that the 
target for retribution is difficult to achieve". The system of parking retribution collection can be improve by electronic machine to print parking tickets so the data automatically recorded and minimize parking fraud, so retribution revenues can increase and encourage an increase regional expenditures.

Balance Funds is a transfer from the central government that is able to increase regional revenues and it used for regional expenditures. The amount of balance funds received by any region depend on the regional financial independence to finance their regional expenditures. Based on data (BPK RI, 2020) "South Sumatra is in the category of "towards to independent" with the average regional financial independence from 2016 to 2019 is $38 \%$, it's mean that regional expenditures are financed by $38 \%$ by South Sumatra original local revenue and the remaining $62 \%$ depends on the balance fund". In 2020, the balance fund will decrease to $60 \%$, it's mean that the balance fund will only finance $60 \%$ of regional expenditures, even though the balance fund needs to be increased so regional expenditures can increases.

When other legitimate regional income increase, it will causes regional revenues also increase, so it will have effect on increasing regional expenditures. The data below is the target and realization of other legitimate regional income from 2016 to 2020.

Table 1 Target and realization of other legitimate regional income in South Sumatra Province in 20162020 .

\begin{tabular}{|r|r|r|}
\hline Year & \multicolumn{1}{|c|}{ Target } & \multicolumn{1}{c|}{ Realization } \\
\hline 2016 & Rp1.590.248.169.235 & Rp1.530.290.904.243 \\
\hline 2017 & Rp3.622.969.217 & Rp1.103.221.135.951 \\
\hline 2018 & Rp88.296.807.800 & Rp100.343.182.502 \\
\hline 2019 & Rp96.250.238.000 & Rp87.530.039.615 \\
\hline 2020 & Rp65.637.725.864 & Rp14.532.195.002 \\
\hline
\end{tabular}

Source : http://www.djpk.kemenkeu.go.id/ (processed data, 2021)

Table 1 shows that other legitimate regional incomes in South Sumatra decrease and failed to reach

the target in 2019 to 2020, this condition was also influenced by the decrease of adjustment funds and special autonomy which became the highest revenue if its compared to other revenues from 2016 to 2020. Adjustment funds and special autonomy are actually useful for financing regional expenditures, however every year South Sumatra always receive that, it's indicating that original local revenue is low and need additional revenue from other legitimate regional income posts. Regional revenues and expenditures will decrease if the adjustment funds and special autonomy as support for other legitimate regional income decrease, because original regional revenues are not sufficient to finance regional expenditures.

Excess of Budget Calculation is considered as government savings that comes from the excess remaining in the previous year's budget. SiLPA is one component of regional financing receipts whose funds can be utilized by the government in financing regional expenditures. This following data show the excess of budget calculation of the South Sumatra Province for 2016 to 2020

Table 2 Excess of Budget Calculation Data of South Sumatra 2016-2020 (in Rupiah)

\begin{tabular}{|l|c|c|c|c|c|}
\hline Year & 2016 & 2017 & 2018 & 2019 & 2020 \\
\hline & 35.579 .268 & 64.859 .465 & 40.929 .016 & 686.485 .024 & 349.152 .583 \\
SiLPA & .821 & .661 & .279 & .490 & .098 \\
\hline
\end{tabular}

Source: http://www.djpk.kemenkeu.go.id/ (processed data, 2021

Sumatra Province is still not stable and tends to increase. SiLPA is actually useful in covering the APBD deficit and financing programs or activities in regional expenditures which is doesn't have budget, but SILPA which tends to increase also shows the amount of regional expenditures that have failed to be realized.

Based on the description above, researcher is interested in taking a discussion about the influence given by local taxes, retribution, balance funds, other legitimate regional income and Excess of Budget Calculation on regional expenditures. The title of this study is "The Factors Affecting Regional Expenditures On Regency/Municipality In South Sumatera Province."

\section{LITERATURE REVIEW}

The concept dan definition of Local Tax takes the grand theory according to Siahaan (2018:7): "Regional taxes is levy from the citizen carried out by the State (government) based on laws that can be imposed and payable by those who are obliged to pay it without receiving direct compensation or remuneration, but the

proceeds are used to finance state expenditures in administering governance and development."

The concept dan definition of Retribution takes the grand theory according to Resmi (2017:2), "Retribution is a levy for the services or facilities which provided by the government directly and clearly to the payer".

The concept dan definition of Balance Fund takes the grand theory according to Wulandari \& Iryanie (2018:11), "Balance funds are funds from APBN which will be allocated to regions, the purpose is to finance 
regional needs, due to the unequal distribution of regional finance and economy".

The concept dan definition of Other Legitimate Regional Income takes the grand theory according to Halim, (2017:172), “Other Legitimate Regional Income is one of the regional incomes that must be maximized as a source of revenues to increase regional financial condition in implementing development programs and services to the citizen."

The concept dan definition of Excess of Budget Calculation takes the grand theory according to Halim (2017:184), "The Excess of Budget Calculation is regional financing receipts that can be used to cover the deficit that occurs".

The concept dan definition of Regional Expenditures takes the grand theory according to Khusaini (2018:164), "Regional expenditures is all of the regional general treasury account which reduces the equity of current funds and can also be interpreted as regional obligations in one fiscal year that have never received any repayment by the region".

\section{RESEARCH METHOD}

This study is quantitative research that will use secondary data from official website of the Directorate General of Fiscal Balance (www.djpk.kemenkeu.go.id) with time-series data from 2016 to 2020 (5 years) and cross section 17 regencies/cities, so that the panel data or samples used are 85 panels or samples. The variables used in this study are the dependent and independent variables. The Independent Variables consist of Local Tax (X1), Retribution (X2), alance Funds (X3), Other Legitimate Regional Income (X4) and Excess of Budget Calculation (X5). Then the Dependent Variable is Regional Expenditures (Y).

According tp Perdana K (2016:67), the definition of classical assumption test is:

If we use o multiple linear regression test, we requires a classical assumption test which statistically must be met to determine whether the specified regression model is the best model and is worthy of being used as a reference for knowledge or practical problem solving solutions.

In analyzing the data in this study, statistic descriptive, classical assumption test (consist of normality test, heteroscedasticity test, autocorrelation test and multicollinearity test), multiple linear regression test, and hypothesis test were used with SPSS For Windows Version 25.00 program.

This research method was chosen to find out the effect of Local Tax, Retribution, Balance Funds, Other Legitimate Regional Income and Excess of Budget
Calculation partially and simultaneously on Regional Expenditures.

\section{RESULT AND ANALYSIS}

Table 3 Result of multiple linear regression

\begin{tabular}{|c|c|c|c|c|c|c|}
\hline \multicolumn{7}{|c|}{$\begin{array}{c}\text { Coeffi } \\
\text { cients }^{\mathrm{a}}\end{array}$} \\
\hline \multirow{2}{*}{\multicolumn{2}{|c|}{ Model }} & \multicolumn{2}{|c|}{$\begin{array}{l}\text { Unstandardized } \\
\text { Coefficients }\end{array}$} & $\begin{array}{l}\text { Standardi } \\
\text { z ed } \\
\text { Coefficie } \\
\text { nt s }\end{array}$ & \multirow[b]{2}{*}{$\mathrm{t}$} & \multirow[b]{2}{*}{ Sig. } \\
\hline & & $B$ & Std. Error & Beta & & \\
\hline 1 & (Constant) & $\begin{array}{r}412110536 \\
08,280\end{array}$ & $\begin{array}{|lr|}22887862 \\
8 & \\
& 57,990 \\
\end{array}$ & & 1,801 &, 076 \\
\hline & Local Tax $\left(\mathrm{X}_{1}\right)$ & 1,045 &, 159 & ,187 & 6,572 &, 000 \\
\hline & Retribution $\left(\mathrm{X}_{2}\right)$ & ,394 & 1,931 &, 006 & ,204 & 839 \\
\hline & $\begin{array}{l}\text { Balance Funds } \\
\left(X_{3}\right)\end{array}$ & 1,033 & ,027 & 694 & 38,678 &, 000 \\
\hline & $\begin{array}{l}\text { Other Legitimate } \\
\text { Regional Income } \\
\left(\mathrm{X}_{4}\right)\end{array}$ & 1,160 & ,084 & ,254 & 13,835 &, 000 \\
\hline & $\begin{array}{l}\text { Excess of Budget } \\
\left.\text { Calculation } X_{5}\right)\end{array}$ & $(480$ & ,099 &,- 060 & $-4,833$ &, 000 \\
\hline
\end{tabular}

Source: processed data, SPSS version 25.00

Based on the table above, the results of the multiple linear regression is:

$\mathrm{Y}=41211053608,280+0,187 \beta 1 \mathrm{X} 1+0,006 \beta 2 \mathrm{X} 2$

$+0,694 \beta 3 X 3+0,254 \beta 4 X 4-0,60 \beta 5 X 5$

1. The constanta 41211053608,280 shows that is $\mathrm{X} 1$, $\mathrm{X} 2, \mathrm{X} 3, \mathrm{X} 4$ dan $\mathrm{X} 5$ equal to 0 , so $\mathrm{Y}$ will be 41211053608,280 .

2. Local Tax has a positive multiple linear regression coefficient of 0,187 , it's mean that if the Local Tax has increased by $1 \%$, then regional expenditures will increase by 0.187 or $18.7 \%$.

3. Retribution has a positive multiple linear regression coefficient of 0,006 , it's mean that if the Retribution has increased by $1 \%$, then regional expenditures will increase by 0,006 atau $0,6 \%$.

4. Balance Funds has a positive multiple linear regression coefficient of 0,694 , it's mean that if the Balance has increased by $1 \%$, then regional expenditures will increase by 0,694 atau $69,4 \%$.

5. Other Legitimate Regional Income has a positive multiple linear regression coefficient of 0,254 it's mean that if the Other Legitimate Regional Income has increased by $1 \%$, then regional expenditures will increase by 0,254 atau $25,4 \%$.

6. Excess of Budget Calculation has a negative multiple linear regression coefficient of $-0,060$, it's mean that if the Excess of Budget Calculation has increased by $1 \%$, then regional expenditures will increase by 0,060 atau $6 \%$ 
Table 4. Result of coefficient of determination test

\begin{tabular}{|c|c|c|c|c|}
\hline \multicolumn{5}{|c|}{$\begin{array}{c}\text { Model } \\
\text { Summar } \\
y^{b}\end{array}$} \\
\hline $\begin{array}{l}\text { Mode } \\
\mathrm{I}\end{array}$ & $\mathrm{R}$ & $\begin{array}{r}R \\
\text { Square }\end{array}$ & $\begin{array}{l}\text { Adjusted } \\
\text { R } \\
\text { Square }\end{array}$ & $\begin{array}{l}\text { Std. Error of } \\
\text { the } \\
\text { Estimate }\end{array}$ \\
\hline 1 & $\begin{array}{c}, 994 \\
\mathrm{a}\end{array}$ & ,988 & ,985 & $\begin{array}{l}92237904353,2 \\
78\end{array}$ \\
\hline \multicolumn{5}{|c|}{$\begin{array}{l}\text { a. Predictors: (Constant), Excess of Budget } \\
\text { Calculation, Retribution, Balance Funds, Other } \\
\text { Legitimate Regional Income, Local Tax }\end{array}$} \\
\hline a. $\quad$ D & epeno & ent Varial & Regional & penditures \\
\hline
\end{tabular}

Source: processed data, SPSS version 25.00

The value of the coefficient determination (R2) in table 2 shows the ability to explain (contribution) of the independent variable to the dependent variable which is calculated through the application of Statistical Product abd Service Solution (SPSS) version 25.00 for windows, so the value of the coefficient determination (R2) is 0.985 which can be seen through the Adjusted R square value. The ability to explain (contribution) of Local Tax (X1), Retribution (X2), Balance Funds (X3), Other Legitimate Regional Income (X4) and Excess of Budget Calculation (X5) to Regional Expenditures (Y ) of 98.5, then the remaining $1.5 \%$ is not included in this study

\section{CONCLUSION}

1. The results show that local tax (X1) has thitung $6,572>$ ttabel 1,990 and significant value of local $\operatorname{tax}(\mathrm{X} 1)$ is $0,00<0,05$. This means that local tax (X1) partially affects the regional expenditures (Y).

2. The results show that retribution (X2) has thitung $0,204<$ ttabel $1,990 \mathrm{~d}$ and significant value of retribution $(\mathrm{X} 2)$ is $0,839>0,05$. This means that retribution (X2) partially does not affects the regional expenditures $(\mathrm{Y})$.

3. The results show that balance funds (X3) has thitung 38,678 > ttabel 1,990 and significant value of balance funds (X3) is $0,00<0,05$. This means that balance funds (X3) partially affects the regional expenditures $(\mathrm{Y})$

4. The results show that Other Legitimate Regional Income (X4) has thitung 13,835 > ttabel 1,990 and significant value of Other Legitimate Regional Income (X4) is $0,00<0,05$. This means that Other Legitimate Regional Income (X4) partially affects the regional expenditures $(\mathrm{Y})$.

5. The results show that Excess of Budget Calculation (X5) has thitung -4,833 > ttabel 1,990 and significant value of Excess of Budget Calculation (X5) is $0,00<0,05$. This means that Excess of Budget Calculation (X5) partially affects the regional expenditures $(\mathrm{Y})$.
6. The results show that Fhitung $1333,801>$ F-tabel 2,330 and significant value $0,000<0,05$ This means that independent variable simultaneously affect dependent variable. So, simultaneously Local Tax (X1), Retributions (X2), Balance Funds (X3), Other Legitimate Regional Income (X4) and Excess of Budget Calculation (X5) have a positive effect to Regional Expenditures (Y).

\section{REFERENCES}

[1] Bpk Ri. (2020). Inspection Report Of Central Government Financial Statement In 2019 Report Of Review On The Fiscal Independence Of Local Governments On 2018 And 2019.

[2] Halim, A. (2017). Management of Public Sector Financial . Jakarta: Salemba Empat.

[3] Khusaini, M. (2018). Regional Finance. Malang: UB Press.

[4] Resmi, S. (2017). Taxation: Theory and Case. Jakarta: Salemba Empat.

[5] Siahaan, M. P. (2018). Local Tax and Retribution. Jakarta: PT Raja Grafindo Persada.

[6] Wulandari, P. A., \& Iryanie, E. (2018). Local Tax in Original Local Government Revenue. Yogyakarta: Deepublish.

[7] Law of Republic Indonesia Number 28 of 2009 concerning Local Tax and Retribution

[8] BritaBrita.com. (2020). Corona Effecr, South Sumatera Regional Revenue fail achieve 50 percent. Syailendra. https://britabrita.com/imbascorona-pendapatan-daerah-sumsel-belum-capai-50persen/ Accessed at February, 19th 2021.

[9] Sripoku.com. (2020). Parking Officers is the cause of failure of retribution achievement. https://palembang.tribunnews.com/2020/02/22/juki r-penyebab-kegagalan-target-retribusi/ Accessed at April, 3rd 2021.

[10] Tempo.co. (2020). Absorption of APBD, Jokowi: Local's government money at Bank is Rp170

Trillion. https://bisnis.tempo.co/read/1365691/soal- serapanapbd-jokowi-uang-pemda-di-bank-masih- rp-170-t/ Accessed at May, 24th 2021.

[11] Perdana K, E. (2016). Study Data Processing with SPSS 22. Bangka Belitung: Lab Kom Manajemen Fe UBB. 